THE JOURNAL OF PHILOSOPHICAL ECONOMICS:

REFLECTIONS ON ECONOMIC AND SOCIAL ISSUES

Volume XIV Issues 1-2

Spring-Autumn 2021

ISSN: $1843-2298$

EISSN: $1844-8208$

Publication date:

20 November 2021

Paper format: $16.5 \times 23.5 \mathrm{~cm}$

Copyright note:

Authors retain unrestricted copyright and all publishing rights in compliance with the Creative Commons license CC BY-NC-SA.
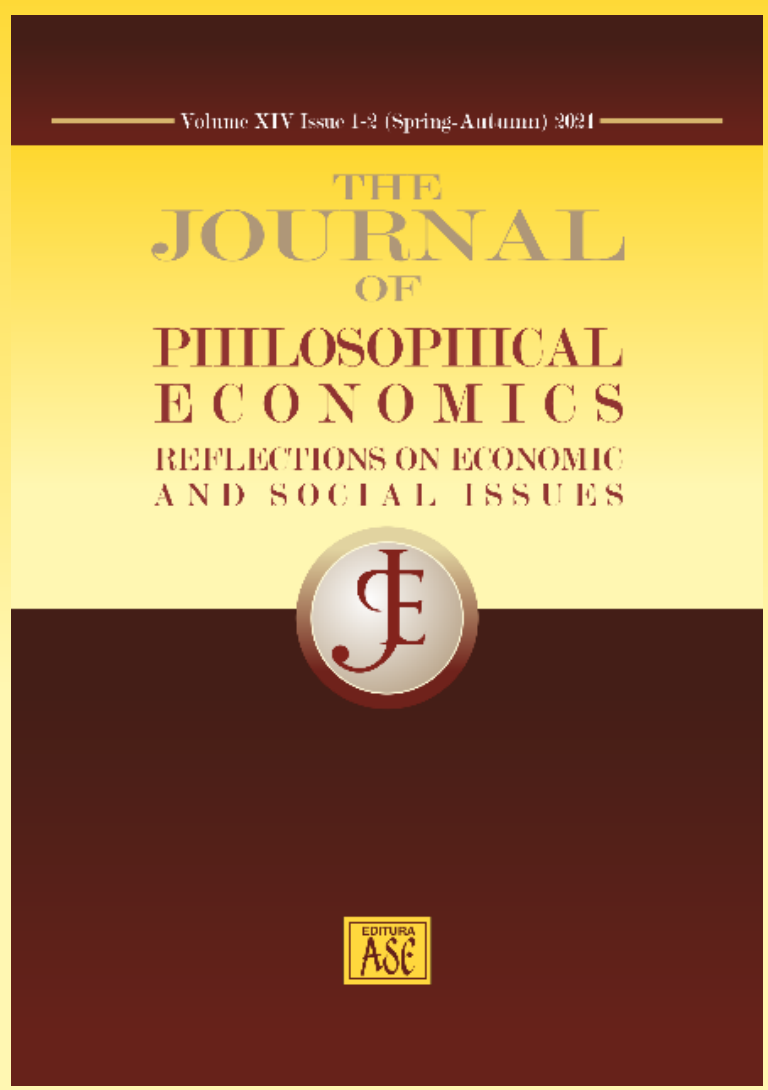

Review of Margaret Schabas and Carl Wennerlind, A Philosopher's Economist: Hume and the Rise of Capitalism, Chicago IL, University of Chicago Press, 316 p., e-book, ISBN 978-0226597447

Mihail-Valentin Cernea 


\section{Review of Margaret Schabas and Carl Wennerlind, A Philosopher's Economist: Hume and the Rise of Capitalism, Chicago IL, University of Chicago Press, 316 p., e-book, ISBN 978-0226597447}

\section{Mihail-Valentin Cernea}

It is no exaggeration to consider David Hume as one of the guiding lights of Enlightenment philosophy - one of the so-called canonical authors that must be read and understood by anyone who aspires to learn the ways of the love of wisdom. His contributions to the fields of metaphysics and epistemology and of moral and political philosophy are keenly discussed even to this day and many authors see Hume as anticipating important research directions in contemporary human sciences, especially in moral psychology (Haidt 2012). This view of Hume contrasts sharply with his perceived role in the development of economics, where he is clearly overshadowed by his younger friend, Adam Smith, who is credited as the main driving force behind the emergence of economics as a science during the Age of Enlightenment. While Hume is not entirely ignored by scholars of economics, his economic ideas have not had the impact of his philosophical endeavors.

Margaret Schabas and Carl Wennerlind, two researchers with important interventions in contemporary Hume scholarship, disagree with this trend in their new and provocative book, A Philosopher's Economist: Hume and the Rise of Capitalism. The two authors attempt to prove that economics was the center of Hume's intellectual preoccupations and that Hume's role in the history of economics should be reconsidered - on the one hand he should be seen as a key figure both in the early epistemology of economics and in the development of the actual theories and tools of this academic field; on the other hand, Hume is also presented as an ardent defender of capitalism as a means to improve human happiness and achieve political stability, whose work was much more popular

Received: 1 September 2021 
Cernea Mihail-Valentin(2021), Review of Margaret Schabas and Carl Wennerlind, A Philosopher's

Economist: Hume and the Rise of Capitalism, Chicago IL, University of Chicago Press, 316 p., e-book, ISBN 978-0226597447, The Journal of Philosophical Economics: Reflections on Economic and Social Issues, XIV (1-2), 260-264

between the men and women of letters at the time than contemporary literature on this subject seems to suggest.

Schabas and Wennerlind proceed through the book using two main approaches: (i) a staggeringly comprehensive account of Humean economics and (ii) a convincing long argument throughout the book maintaining that Hume's entire philosophical work can better be understood when economics is seen as its 'unifying theme', a field in which both his philosophical and historical works collide and coalesce into a science of human affairs. The book begins with a biographical chapter that is designed to provide both historical background and historical proof for the underestimated importance of David Hume, the economist. Through a remarkable mastery of both primary and secondary sources, Hume is revealed here as having an avid interest in political economy, pursued throughout his life. He even amassed tons of statistical data about various aspects of the global economy which he used for estimations and hypothesis testing. The second chapter provides philosophical context for Hume's views on the epistemology of economics. Schabas and Wennerlind manage to put a final nail in the coffin of the oft repeated historically inaccurate intuition that the scientific endeavor of understanding human nature specific to Scottish Enlightenment is built in the mold of natural science, following the success of Newtonian mechanics. Rather than an admirer of Newton, Hume is shown to be quite skeptical of the occult nature of gravity (p. 58). Natural sciences, in Hume's view, provide lesser opportunities to correct errors, as the researcher studies objects generally situated outside their own nature. Building a solid science of the human seems more likely for Hume, as at least some falsehoods about humans would be more immediately apparent to the human scholar (Hume 2000). Thus, for Hume (and for Adam Smith), economics could provide even better experimental knowledge than physics, for example, precisely because it was not a natural science and had access to the breadth of human experience as an empirical testbed. Therefore, Humean economics differs from contemporary approaches through its ambitious 'historical sweep', using the past as a source of data and experimentation (p. 52). Moreover, Schabas and Wennerlind underline his basic assumption that human behavior had enough uniformity to be generalized into scientific principles that could be used in its understanding and improvement. The laws of human behavior were discoverable, but only 
Cernea Mihail-Valentin (2021), Review of Margaret Schabas and Carl Wennerlind, A Philosopher's

Economist: Hume and the Rise of Capitalism, Chicago IL, University of Chicago Press, 316 p., e-book, ISBN 978-0226597447, The Journal of Philosophical Economics: Reflections on Economic and Social Issues, XIV (1-2), 260-264

through careful observation, probabilistic reasoning, and quantitative research - all pillars of economics even to this day. Introspection, though, is not as highly regarded in scientific methodology.

The third and fourth chapters deal with Hume's views on capitalistic societies, discussing his analysis of property and commerce and their role in shaping up societies and his various accounts of the link between economic and human improvement. Commercial societies, for Hume, 'were on a trajectory that served to achieve the proper mix of prudence and trust, discipline and order, industry and pleasure, all in the name of individual and collective happiness' (p. 112). This positive trajectory was mostly influenced by contractual obligations and the kinds of institutions that they entail in situations of large-scale human cooperation. Mutual and self-interest work together in these commercial contexts, and they incentivize respecting others and the pursuit of knowledge. It is worth stressing that Hume saw the moral betterment of society as an indirect effect of industry and commerce and not something that could be politically imposed by some magistrate. While not a direct appeal to the mechanism of the 'invisible hand' that Adam Smith would later propose, the two authors do point out that Hume's optimism regarding the future of capitalistic societies could be seen as a 'progenitor' for Smith's widely know contribution to the founding of economics (p. 141).

Hume's specific contributions to the scientific studies of the political economy are analyzed in the fifth and sixth chapters of the book, putting the focus, in turn, on money and banks and on international trade and public finance. Particularly on money, Hume's work has been applauded both by his contemporaries and current scholars of economic and Schabas and Wennerlind are no different, directly referring the Hume's theory of money as 'arguably brilliant' (p. 176), as it managed to not only provide new understanding on the connection between money and wealth, but to provide new levels of abstraction and generality that showed once and for all that the institution of money had its own principles and laws upon which humans could only exert limited control. Money could be seen as an empirical proof for the previously mentioned natural laws of human behavior (Hume 1985, pp. 281-294). On international trade, Hume takes the potential of commerce and of its norms and incentives to pacify societies and 
Cernea Mihail-Valentin(2021), Review of Margaret Schabas and Carl Wennerlind, A Philosopher's

Economist: Hume and the Rise of Capitalism, Chicago IL, University of Chicago Press, 316 p., e-book, ISBN 978-0226597447, The Journal of Philosophical Economics: Reflections on Economic and Social Issues, XIV (1-2), 260-264

extends it to the international level. For peace between nations to be possible, trade must flow. Peace is paramount for Hume, because it brings with it a reduction of public debt, one of the greatest obstacles to political stability that a country may face. During his age, most public spending was directed at the military, as war was an unfortunately common occurrence. Thus, public debt financed conflicts and created a rentier class, who traded in debt and who, in Hume's view, does not contribute meaningfully to society, as it benefits when the other members of society falter (pp. 195-204).

The last chapter of the book concludes the argument that economics is the unifying theme of David Hume's diverse writings and follows his influence across history. The authors do really succeed at providing a fascinating view of Hume through the eyes of other intellectual giants like Milton Friedman, John Maynard Keynes, Friedrich Hayek, or James Buchanan. Thus, Schabas and Wennerlind underline the value of Hume for economics, not just the value of economics for Hume.

A Philosopher's Economist manages to be two books at once in one coherent whole. On the one hand, Schabas and Wennerlind offer thoroughly researched context for Hume's economics, both as a part of his own oeuvre and in the larger intellectual and political environment of his age. The authors take great care when using terms that may incur charges of anachronism, either by arguing for their choice or by specifying the meaning and use of the term during Hume's life. On the other, this is not just a historical work with a detailed literature review, but a provocative argument for a plausible thesis which should generate debates in contemporary Hume exegesis and provide a great starting point for future research.

While Hume is without a doubt an optimist regarding the potential of capitalism to bring prosperity and happiness to societies, even more so than Adam Smith (p. 1), he is clear-eyed regarding the way it could stray off course, particularly in fickle political republics and economic crises. What he overestimated was the capacity of commerce to foster peace, as the centuries of conflict that followed clearly demonstrate, even though he was not as optimistic as his some of his contemporaries in hoping for perpetual peace. The influence of Scottish Enlightenment over the methodological and scientific development of economics 
Cernea Mihail-Valentin (2021), Review of Margaret Schabas and Carl Wennerlind, A Philosopher's

Economist: Hume and the Rise of Capitalism, Chicago IL, University of Chicago Press, 316 p., e-book, ISBN 978-0226597447, The Journal of Philosophical Economics: Reflections on Economic and Social Issues, XIV (1-2), 260-264

as a field cannot be overstated. Usually, one looks at Adam Smith to see the precise moment when economics begins to be delineated from moral and political philosophy. Schabas and Wennerlind make good case that Hume might be a better starting point for the historian and philosopher of the human sciences, as the scope of his work encompasses all the different dots that must be connected when trying to build a science of human nature.

\section{References}

Haidt, Jonathan (2012), The Righteous Mind: Why Good People Are Divided by Politics and Religion, New York: Pantheon Books.

Hume, David (1985), Essays: Moral, Political, and Literary, revised edition by E. F. Miller, Indianapolis: Liberty Classics.

Hume, David (2000), An Enquiry Concerning Human Understanding, edited by T. L. Beauchamp. Oxford: Clarendon.

Mihail-Valentin Cernea is an Assistant Professor in philosophy and business ethics at the Bucharest University of Economics Studies, Bucharest (Romania) (mihai.cernea@man.ase.ro). 